Paedagogia Christiana

I/27 (20I I) - ISSN 1505-6872

Magdalena Lewicka*

Toruń

\title{
Dialog chrześcijańsko-muzułmański Historia i współczesność, zagrożenia i wyzwania, Toruń, 18-19 października 2010 roku
}

\begin{abstract}
Dialog pozwala dostrzec, że różnorodność jest bogactwem i skłania umysły ludzi do wzajemnej akceptacji, prowadzącej do autentycznej współpracy. Jest zatem znakomitym narzędziem budowania cywilizacji miłości i pokoju, jako ideał, na którym winno się wzorować życie kulturalne, społeczne, polityczne i ekonomiczne naszej epoki ${ }^{1}$.
\end{abstract}

Jan Paweł II

Jednym z procesów, a jednocześnie ogromnych wyzwań, kształtujących oblicze XXI wieku, jest dialog między cywilizacjami, którego nieodłącznym elementem jest dialog międzyreligijny, w tym dialog pomiędzy chrześcijaństwem a islamem. $Z$ chrześcijańskiego punktu widzenia dialog ten nabiera szczególnie ważnego znaczenia tu i teraz, kiedy Kościoły naszego kontynentu stają w obliczu zwiększającej się obecności muzułmanów, która zmienia sytuację historyczna, kulturową i religijną Europy, zdominowaną jeszcze do niedawna przez chrześcijaństwo. Stąd potrzeba podjęcia działań promujących dialog między przedstawicielami różnych cywilizacji i wyznań oraz wspólpracę międzynarodową opartą na tolerancji i uznaniu unikalności

* Dr Magdalena Lewicka, arabistka i islamolog, kierownik Pracowni Języka i Kultury Arabskiej Uniwersytetu Mikołaja Kopernika w Toruniu.

1 Jan Paweł II, Orędzie na XXXIV Światowy Dzień Pokoju „,Dialog między kulturami droga do cywilizacji mitosierdzia i pokoju”, Watykan, 8 grudnia 2000. Pełny teksy orędzia dostępny na www.kns.gower.pl/pokoj/pokoj2001.htm. (10.10.2010). 
wkładu różnych kultur i religii w rozwój ludzkości, prowadzących do wzajemnego poznania oraz przezwyciężenia narosłych z biegiem lat stereotypów. Jedną z takich inicjatyw była międzynarodowa konferencja naukowa Dialog chrześcijańsko-muzulmański. Historia i współczesność, zagrożenia $i$ wyzwania, która odbyła się w dniach 18-19 października 2010 w gmachu Wydziału Filologicznego UMK. Celem przyświecającym spotkaniu naukowców z kraju i z zagranicy było przedstawienie genezy i historii dialogu pomiędzy chrześcijaństwem i islamem, analiza zasad konstruktywnego dialogu pomiędzy tymi wyznaniami, a także omówienie zagrożeń i wyzwań, jakie stoją przed owym dialogiem u progu XXI wieku.

Konferencja została objęta honorowym patronatem władz miasta i województwa. Marszałek Województwa Kujawsko-Pomorskiego, Piotr Całbecki, podkreślał, że: „Tematyka przedsięwzięcia dotycząca współpracy międzynarodowej opartej na tolerancji dla innych wyznań i poglądów, doskonale wpisuje się w politykę rozwoju województwa prowadzoną przez jego samorząd. Problematyka, której dotyka kampania, jest obecnie bardzo aktualna i wyjątkowo ważna"2, natomiast Prezydent Miasta Torunia Michał Zaleski wyraził przekonanie, że: „Przedsięwzięcie przyczyni się do propagowania dialogu międzywyznaniowego, prowadzącego do prawdziwego poznania obu religii, wzajemnego szacunku i współdziałania, dzięki któremu będziemy mogli razem sprostać wyzwaniom współczesności”’3.

Uczestnicy konferencji, orientaliści, kulturoznawcy, religioznawcy, politolodzy, historycy i reprezentanci innych dyscyplin naukowych, związanych z tematyką przewodnia, postawili sobie za cel wymianę doświadczeń i poglądów naukowych badaczy dialogu pomiędzy chrześcijaństwem i islamem, dlatego spotkanie zgromadziło nie tylko przedstawicieli polskiej, ale i zagranicznej sceny naukowej - z USA, Niemiec, Rosji - zajmujących się wzajemnymi relacjami wyznawców obu wyznań. Gościem honorowym naukowego spotkania była dr Jill Carroll, profesor religioznawstwa Rice University w Houston, wieloletni dyrektor Centrum Boniuk Badania i Propagowania Tolerancji Religijnej, pomysłodawca i dyrektor projektu „Niesamowite Religie", międzywyznaniowego programu opartego na współpracy pomiędzy przedstawicielami różnych religii, orędowniczka porozumienia i współdziałania międzywyznaniowego i międzykulturowego, działaczka społeczna, publicystka, autorka wielu artykułów i publikacji książkowych,

${ }^{2}$ Cytat z pisma Dyrektora Gabinetu Marszałka Województwa Kujawsko-Pomorskiego, Beaty Sawińskiej, skierowanego do sekretarza konferencji, dr Magdaleny Lewickiej, z dnia 27.07.2010 roku (nr ref. GM.R.P.066/343/210).

${ }^{3}$ Cytat z pisma Prezydenta Miasta Torunia, Michała Zaleskiego, skierowanego do Dziekana Wydziału Filologicznego UMK, dr hab. Adama Bednarka, prof. UMK, z dnia 03.08.2010 roku (nr ref. WWZiI.RWZ.0717.1-141/10). 
z których najnowsza, Dialog cywilizacji. Muzutmańskie ideały Gülena a dyskurs humanistyczny ${ }^{4}$, została ogłoszona przez magazyn „Publishers Weekly” bestsellerem roku 2007.

W uroczystości otwarcia konferencji i spotkaniach przewidzianych na pierwszy dzień wydarzenia udział wzięły władze Uczelni, miasta i województwa, przedstawiciele środowisk naukowych, a także dyplomaci z krajów arabskich i muzułmańskich w RP. Obrady otworzył kierownik naukowy konferencji, dr hab. Czesław Łapicz, prof. UMK, mówiąc: „Od dialogu z islamem zależy dziś przyszłość świata. Tak rangę i znaczenie międzyreligijnego dialogu widzi i ocenia papież Benedykt XVI, który słowa te wypowiedział 29 sierpnia 2006 roku podczas spotkania z przedstawicielami świata islamu w Castel Gandolfo". Witając zgromadzonych gości i uczestników konferencji zacytował słowa Abrahama Joshuy Heschela: „Żadna religia nie jest samotną wyspa; wola Boża i objawienie Bożej obecności w świecie ukazują się bowiem raczej jako archipelag” i dodał: „Dzisiaj przedstawiciele dwóch dużych wysp religijnego archipelagu spotykają się w Toruniu, w historycznym mieście dialogu, w którym już w roku 1645 odbyło się jedyne w swoim rodzaju międzywyznaniowe spotkanie, znane w historii pod nazwą Colloquium Charitativum". Do tego, zwołanego z inicjatywy króla Władysława Wazy IV i biskupów, zaniepokojonych wzrastającą nietolerancją religijną i wzajemną nienawiścią, zjazdu, w którym udział wzięło ponad siedemdziesięciu teologów i przedstawicieli luteranów, kalwinistów i katolików, nawiązywali także kolejni mówcy: Prorektor UMK, prof. dr hab. Witold Wojdyło, Wicemarszałek Województwa Kujawsko-Pomorskiego, Maciej Eckardt i Prezydent Miasta Torunia Michał Zaleski. Ta bowiem „braterska rozmowa” - uznana przez historyków za jedną z pierwszych w dziejach próbę doktrynalnego dialogu ekumenicznego - znalazła swoją kontynuację w postaci organizowanych cyklicznie od roku 1995 przez Urząd Miasta Torunia, Uniwersytet Mikołaja Kopernika, Kurię Diecezjalną i Towarzystwo Naukowe w Toruniu międzyreligijnych dialogów pod nazwą Colloquia Torunensia.

Po przedstawicielach uczelni, miasta i województwa głos zabrał J.E. Ambasador Algierii w RP i zarazem Dziekan Ambasadorów Państw Muzułmańskich akredytowanych w Polsce, Abdelkader Khemri, który zauważył, że: „Islam jest jedną z trzech największych, obok chrześcijaństwa i judaizmu, religii monoteistycznych, a także kluczowym elementem w wysiłkach

${ }^{4}$ B. Jill Carroll, Dialog cywilizacji. Muzutmańskie ideaty Gülena a dyskurs humanistyczny, Warszawa 2010.

${ }^{5}$ Patrz: B. L. Sherwin, H. Kasimow, Żadna religia nie jest samotnq wyspq. Abraham Joshua Heschel i dialog międzyreligijny, Warszawa 2005. 
ludzkości, podejmowanych od przełomu XX i XXI wieku, określanych mianem dialogu pomiędzy religiami i cywilizacjami. Analiza tych zagadnień, mimo świadomości, iż wymagają one wkładu ogromnego wysiłku, pozwala dostrzec prawdę dotyczącą ludzkiego istnienia, dla którego fundamentem jest dobro, miłość oraz poświęcenie na rzecz obrony prawdy i wartości stanowiących podstawy współżycia i współistnienia w pokoju, zrozumieniu, tolerancji i akceptacji drugiego człowieka, przy jednoczesnym odpieraniu wszelkich przejawów zła, jakimi są przemoc, rasizm i agresja. Społeczność muzułmańska, a wraz z nią najwybitniejsi naukowcy i intelektualiści zdali sobie sprawę z faktu, że walka ta, walka pokojowego współistnienia i dialogu jest jedynym sposobem przezwyciężenia niesprawiedliwości i wszelkich form alienacji, a celem, na rzecz którego podejmuje poważne wysiłki, jest stworzenie przestrzeni dla dialogu między religiami i cywilizacjami jako mechanizmem prowadzącym do porozumienia i rozwoju".

Pierwszej części obrad, która wprowadziła uczestników spotkania w tematykę przewodnia, przewodniczył dr hab. Czesław Łapicz, prof. UMK (Toruń). Zagadnienie dialogu chrześcijańsko-muzułmańskiego w świetle nauczania Jana Pawła II przybliżył prof. dr hab. Eugeniusz Sakowicz (UKSW, Warszawa), podkreślając, że: „Papież ten budując teorię dialogu Kościoła $\mathrm{z}$ islamem czerpał z Biblii, inspirował się głębią teologii pisarzy wczesnochrześcijańskich, odwoływał się do antropologii filozoficznej. Wypowiedzi papieskie o islamie, spotkania z muzułmanami „twarzą w twarz”, wszystkie gesty i czyny dialogu miały wymiar pedagogiczny. Podobnie formy dialogu - które Jan Paweł II wskazywał - mają wymiar pedagogiczny: dialog chrześcijan i muzułmanów w życiu codziennym, ale też dialog specjalistów w naukach teologicznych (czyli teologów chrześcijaństwa i islamu), jak również dialog modlitwy, polegający na „byciu razem, aby się modlić” (według własnych reguł doktryny i kultu), czy wreszcie dialog społecznego zaangażowania na rzecz wyzwalania z niemoralności (a więc promocja życia ludzkiego - indywidualnego oraz społecznego). Teologia dialogu bez pedagogiki dialogu byłaby tylko ,piękną mową”. Jan Paweł II uczył i wychowywał katolików do pięknych czynów, czyli do bezwarunkowej afirmacji wszystkich bliźnich, w tym wyznawców islamu". Historię i perspektywy dialogu chrześcijańsko-muzułmańskiego w Polsce szczegółowo omówił mgr Adam Murman, występując w imieniu nieobecnego dr hab. Selima Chazbijewicza, prof. UWM (Olsztyn). Podobnie jak inni referenci zaznaczył, że: „Dialog chrześcijańsko-muzułmański w Polsce ma wieloletnią, a nawet wielowiekową tradycję, która wynika z 600 lat pokojowego współistnienia chrześcijaństwa i islamu na ziemiach Rzeczypospolitej”. Kolejnego prelegenta, Muftiego RP Tomasza Miśkiewicza, zastapił natomiast członek Najwyższego Kolegium MZR i rzecznik tejże organizacji, Musa Czachorowski, 
który szczegółowo omówił historię i działalność Tatarów-muzułmanów we współczesnej Polsce. Jak powiedział: „Nasi Tatarzy są najstarszą, właściwie już rdzenną, muzułmańską mniejszością w tej części Europy. To prawdziwy ewenement - ponadsześćsetletnie trwanie odrębnej wiary i tradycji w gruncie rzeczy bez konfliktów z miejscowym katolicyzmem, prawosławiem, protestantyzmem i judaizmem". Warto zacytować także słowa, którymi zakończył swoje wystapienie: „I tak trwa przez wieki muzułmańska wiara w sercu Europy, w zgodzie z polskim katolicyzmem, prawosławiem, judaizmem. Tatarscy muezini wciąż pieją wezwanie do piątkowego namazu. Niegdyś przez stulecia służyli Tatarzy władcom Rzeczypospolitej Obojga Narodów nie tylko orężnie, ale i jako posłowie do tureckich sułtanów czy chanów krymskich. Byli kurierami, tłumaczami oraz przewodnikami. Pozostali wierni swojej religii muzułmańskiej i słowiańskiej Ojczyźnie. Dzisiaj mogą być pomostem między Polską a światem Orientu, między islamem a chrześcijaństwem". Szczególne znaczenie miał ostatni referat sesji otwierającej, wygłoszony przez dr Agatę Skowron-Nalborczyk (UW, Warszawa), a mianowicie - Jednakowe stowo dla nas i dla was-następstwa wyjatkowego gestu muzulmanów wobec chrześcijan w dialogu chrześcijańsko-muzutmańskim, która omówiła list skierowany w 2007 roku przez muzułmańskich uczonych i liderów z różnych regionów świata do przywódców chrześcijańskich „,z zaproszeniem do podjęcia wspólnej, teologicznej refleksji nad tym, co łączy obie wielkie tradycje religijne oraz do wspólnego budowania pokoju na świecie. Uczeni muzułmańscy omawiają w nim przykazanie miłości Boga oraz miłości bliźniego, które według nich są wspólne obu religiom i mogą stanowić podstawę w dialogu między ich wyznawcami”.

W sesji drugiej, moderowanej przez prof. dr hab. Eugeniusza Sakowicza, znalazły się wystapienia referentów z zagranicy: dr Jill Carroll (Rice University, Houston), dr Arhana Kardaša (Zukunft Medien GmbH, Niemcy) i dr Stanisława W. Dumina (Państwowe Muzeum Historyczne, Moskwa). Celem dwóch pierwszych było przedstawienie idei dialogu w ujęciu wpływowego intelektualisty tureckiego i uczonego muzułmańskiego, Fethullaha Gülena, „którego koncepcje w odniesieniu do przyrodzonej wartości człowieka i jego godności, swobody myśli, edukacji oraz podejmowania odpowiedzialności za współtworzenie społeczeństwa i świata stanowią wyzwanie i znakomitą okazję do lepszego zrozumienia tego, co dialog międzyreligijny oferuje ludziom XXI wieku". Kolejny mówca opowiadał natomiast o problemie chrystianizacji Tatarów Wielkiego Księstwa Litewskiego w świetle źródeł, nawiązując do tradycji genealogicznych i legend herbowych Tatarów Wielkiego Księstwa Litewskiego.

W popołudniowej części programu konferencji znalazło się spotkanie z podróżnikiem, dr Zdzisławem Preisnerem (WSG, Bydgoszcz), Perly ar- 
chitektury - najpiękniejsze światynie islamu i chrześcijaństwa, prezentujące najcenniejsze, a zarazem najpiękniejsze dzieła twórców architektury sakralnej obu wyznań - ,świątyń chrześcijańskich, o tak zmieniającej się na przestrzeni wieków architekturze, wznoszonych z kamienia, cegły, drewna, przede wszystkim w krajach Europy, ale także w Nowym Świecie na kontynentach amerykańskich oraz meczetów w krajach Afryki Północnej, Bliskiego Wschodu, Azji Południowo-Wschodniej" - uwiecznione na fotografiach wykonanych przez autora w różnych zakątkach świata.

Wydarzeniem zamykającym pierwszy dzień obrad, a jednocześnie nawiązującym do tematyki przewodniej konferencji, był koncert w wykonaniu Camerata Vladislavia dedykowany pamięci Jana Pawła II jako orędownika dialogu międzyreligijnego, który zgromadził miłośników muzyki poważnej w Sali Mieszczańskiej Ratusza Staromiejskiego.

Na kolejny dzień konferencji złożyły się dwie sesje, z których pierwsza, prowadzoną przez dr Agatę Skowron-Nalborczyk, otworzył referat dr Marcina Grodzkiego (UW, Warszawa), wprowadzający zebranych w tajniki „tajemniczych liter Koranu", te bowiem odczytane na nowo mogą stanowić przyczynek do dialogu chrześcijańsko-muzułmańskiego, jako że: „Ostatnio opublikowana nowa naukowa teoria zachodnioniemieckich semitystów skupionych wokół Uniwersytetu Kraju Saary, wskazuje na analogie łączące fakt oznaczenia sur koranicznych sekretnymi literami z faktem podobnych oznaczeń, używanych do dziś w zachodnio-syryjskich księgach liturgicznych". Tematykę przenikania religijnego muzułmańsko-chrześcijańskiego kontynuował dr Artur Konopacki (Uniwersytet w Białymstoku), współprzewodniczący Rady Wspólnej Katolików i Muzułmanów, który scharakteryzował dwa środowiska chrześcijan i muzułmanów żyjących na ziemiach Wielkiego Księstwa Litewskiego i miejsca życia duchownego, które stawały się wspólne dla obu religii. Jak zauważył: „Dzięki specyfice pokojowego współistnienia muzułmanów-Tatarów i chrześcijan obok siebie wytworzyły się niezwykle ciekawe relacje związane z postrzeganiem miejsc kultu obcych religijnie. Były to miejsca, do których można się udać po pomoc. Takim niewątpliwie miejscem był klasztor dominikanów w Różanymstoku, do którego miejscowe tatarki udawały się, aby przed obrazem prosić o wstawiennictwo za zdrowie. I z drugiej strony cmentarz tatarski w Łowczycach z grobem św. Kontusia, który był odwiedzany przez chrześcijańskie kobiety pragnące zajść w ciążę". Wymianie poglądów i doświadczeń związanych $\mathrm{z}$ badaniami nad rzeczywistym dialogiem międzyreligijnym, który toczy się w jednym z krajów Bliskiego Wschodu, służyło wystapienie dr Marty Woźniak (UŁ, Łódź), prezentujące historię, założenia i najistotniejsze dokonania wspólnoty syryjskiego klasztoru p.w. św. Mojżesza Abisyńskiego, Dajr Mar Musa, stawiającego sobie za jeden z głównych celów działalności pracę na 
rzecz polepszenia stosunków chrześcijańsko-muzułmańskich. Do dokonań Jana Pawła II na polu działalności dialogicznej nawiązała natomiast ostatnia prelegentka tejże sesji, dr Dorota Rudnicka-Kassem (UJ, Kraków) w swoim referacie „Wojna nie jest rozwiqzaniem”: dialog międzyreligijny Jana Pawła II jako program pokoju i stabilizacji na Bliskim Wschodzie, zaczynając wystapienie od stwierdzenia, że: „W pokojowej strategii Jana Pawła II rozwijanej z perspektywy świadka ludzkiej godności i nadziei na lepszą przyszłość szczególne miejsce zajmował Bliski Wschód, a rozwijany przez Papieża dialog międzyreligijny w duchu soborowej deklaracji Nostra Aetate był jej najlepszym narzędziem”, a kończąc je słowami: „To właśnie jego stanowczość i wytrwałość, obiektywizm i pragmatyzm, a przede wszystkim wielki autorytet moralny i wiarygodność sprawiły, że zdołał uchronić relacje między islamem i chrześcijaństwem przed wojną religijną i dzięki temu, dalekosiężny cel Jana Pawła II - pokój i bezpieczeństwo na Bliskim Wschodzie jest ciagle możliwy".

W ostatniej sesji, której moderatorem był dr Stanisław Dumin, wystąpił dr Bartłomiej Grysa z analizą tekstu średniowiecznej debaty o. Jerzego z klasztoru św. Szymona Słupnika z trzema muzułmańskimi uczonymi, która choć zdaniem badaczy „najprawdopodobniej nigdy nie miała miejsca w konkretnych ramach historycznych, to jej treść stanowi bogate źródło wiedzy o dialogu chrześcijańsko-muzułmańskim przełomu XII i XIII wieku w Syrii. Liczne argumenty, używane przez obydwie strony w sposób szczery i otwarty, pojawiają się $\mathrm{w}$ wielu pismach apologetycznych chrześcijan Bliskiego Wschodu zarówno w okresie średniowiecza, jak i późniejszym, stąd tego rodzaju piśmiennictwo rzuca światło na kwestię wzajemnych odniesień wyznawców chrześcijaństwa i islamu oraz ich wiedzy na temat religii drugiej strony w omawianym okresie”. Mgr Monika Ryszewska (UMK, Toruń) przedstawiła wykład pt. Dialog chrześsijańsko-muzułmański na przykładzie Niemiec. Omówienie działań podejmowanych przez obie strony na przestrzeni ostatnich lat oraz próba scharakteryzowania trudności stojących na drodze do efektywnego i otwartego dyskursu stały się przedmiotem burzliwej dyskusji. Referatem zamykającym obrady było wystapienie dr Magdaleny Lewickiej (UMK, Toruń), w którym przybliżyła genezę, cele i działalność Rady Wspólnej Katolików i Muzułmanów, której zadaniem jest: „Dialog pomiędzy obu religiami oraz cywilizacjami: łacińską i muzułmańska, jako jeden z elementów dialogu międzykulturowego, który kształtuje oblicze XXI wieku”, bowiem „Świat współczesny stoi przed wieloma trudnymi wyzwaniami, które będą coraz silniej zaznaczały swoją obecność w XXI wieku, jak: pluralizm społeczny i narodowościowy, wzrost nacjonalizmów i agresji w stosunkach międzyludzkich, perspektywa konfliktów cywilizacji, zniszczenie środowiska naturalnego i przeludnienie, powstanie olbrzymich obsza- 
rów nędzy, rozpad tradycyjnych więzów rodzinnych i społecznych, upadek hierarchii wartości i norm etycznych. Stają przed tymi problemami również wyznawcy dwóch największych religii monoteistycznych - chrześcijaństwa i islamu. Wymaga to dialogu, współpracy, wzajemnego poszanowania dla obrony tych obszarów, form życia społecznego, które są wspólne dla katolików i muzułmanów".

Ostatnim etapem było podsumowanie konferencji, którego dokonał prof. dr hab. Eugeniusz Sakowicz, analizując i komentując zarówno przedstawione przez referentów wykłady, jak i dyskusje, będące zwieńczeniem kolejnych części obrad. Warto zacytować jego słowa: „Dialog zawsze napotykał na rozliczne trudności. Uważam, że piętrzące się trudności na drodze spotkania ludzi rożnych kultur, religii i mentalności są wielkim wyzwaniem i zadaniem dla każdej strony. Nie będą one zagrożeniami, jeśli przejdzie się ponad nimi. Dialog to pokonywanie tego, co wydaje się nie do pokonaniaresentymentów, dramatycznych wspomnień całych wcześniejszych pokoleń, które nie pozwalają pokoleniom młodszym być sobą. Dialog uczy szacunku wobec drugiego, ale też jest wyrazem respektu dla samego siebie, dla własnej tożsamości. Tylko ten, kto wie, kim jest, może podjać i prowadzić dialog. Jedynie ten, który czuje się szczęśliwy we własnej wspólnocie życia, ale i wiary będzie zdolny do twórczej rozmowy, twórczej, bo „stwarzającej” nowe relacje. Dialog to nie tylko wymiana zdań, to także bycie razem w tym samym miejscu, to nawet milczenie, to skupienie się na tym, co stanowi o wartości życia ludzkiego - na prawdzie, dobru i na tym, co jest piękne. Celem dialogu międzyreligijnego jest Bóg, różnie pojmowany, ale ostatecznie jeden, jedyny. Dialog to zarówno dyskurs intelektualny, jak i emocjonalne usposobienie. Człowiek prowadzący dialog może w pełni siebie zrozumieć dzięki drugiemu. Ten, kto nie rozmawia z drugim, ten się zamyka również na siebie. Przypomina równocześnie twierdzę, która oblegana jest przez niego samego, przez jego lęk przed obcym. Dialog zaś to otwartość, zaufanie, pokój”.

Organizatorzy konferencji wyrazili nadzieję, że tegoroczna edycja zainicjuje cykl podobnych spotkań, które odbywać się będą w październiku każdego roku i wpiszą się na stałe w kalendarz kulturalno-naukowych wydarzeń Torunia, podobnie jak jesienne debaty międzyreligijne Colloquia Torunensia. Z całą pewnością przygotowując je organizatorzy wychodzą naprzeciw oczekiwaniom tych wszystkich, którzy zainteresowani są działalnością dialogiczną i relacjami pomiędzy chrześcijaństwem a islamem, dają im okazję choć po części zaspokoić potrzebę poznania świata muzułmańskiego, pozwalają na podjęcie próby zrozumienia punktu widzenia wyznawców islamu, wreszcie - stworzenia nici porozumienia, poszanowania, tolerancji i akceptacji jako punktu wyjścia dla autentycznego dialogu. Kon- 
ferencja Dialog chrześcijańsko-muzutmański. Historia i wspótczesność, zagrożenia $i$ wyzwania wniosła zatem nie tylko ciekawy wkład w życie kulturalno-naukowe Torunia i UMK, jako wydarzenie o charakterze kulturalnym, naukowym, religijnym czy społecznym, ale przede wszystkim przyczyniła się do propagowania i realizowania idei dialogu, by - zgodnie ze słowami Jana Pawła II - „móc w pokoju współistnieć i wzajemnie się ubogacać”. 